\title{
Endogenous Financial and Trade Openness
}

\author{
Joshua Aizenman and Ilan Noy*
}

\begin{abstract}
The authors study the endogenous determination of financial and trade openness. They construct a theoretical framework leading to two-way feedbacks between financial and trade openness and identify these feedbacks empirically. They find that one standard deviation increase in commercial openness is associated with a $9.5 \%$ increase in de facto financial openness (\% of GDP). Similarly, an increase in de facto financial openness has powerful effects on future trade openness. De jure restrictions on capital mobility have only a weak impact on de facto financial openness, while de jure restrictions on the current account have a large adverse effect on commercial openness. The authors investigate the relative magnitudes of these directions of causality using Geweke's (1982) decomposition methodology. They conclude that in an era of rapidly growing trade integration, countries cannot choose financial openness independently of their degree of openness to trade. Dealing with greater exposure to turbulence by imposing restrictions on financial flows is likely to be ineffectual.
\end{abstract}

\section{Introduction and Overview}

Salient features of the international economy during the last 20 years are the growing financial and commercial integrations of developing countries and the recurring financial instabilities and crises. These developments have led to contentious debates regarding the desirability of financial openness. Prominent economists have concluded that the gains from financial integration are illusive and caution developing countries against rushing towards financial openness (Rodrik, 1999). Yet, other studies have provided tentative support for the presence of significant gains (Henry, 2003). While some observers conclude that greater exposure to financial turbulence should be dealt with by curbing financial flows, others caution against capital controls noting their ineffectiveness. These issues are of crucial importance to, for example, China and India, as both have increased their trade openness while sustaining financial repression. This debate presumes that countries can choose their desirable level of financial openness independently of their degree of openness to trade.

Past studies typically focus on the formal acts associated with de jure financial opening, such as changing regulations. Yet, as has been noted by Prasad et al. (2003), de facto financial integration is by itself of considerable interest. The actual level of financial openness is the outcome of the interaction between market forces and the enforcement of existing regulations. We utilize the concepts of de facto trade and financial integration to investigate this presumption, and we study the two-way feedbacks between de facto financial and trade openness and the residual role of de jure openness. After outlining a model, we show that de facto financial openness depends positively on lagged trade openness.

\footnotetext{
* Aizenman: University of California, Santa Cruz, CA, 95064, USA. E-mail: jaizen@ucsc.edu. Noy: University of Hawaii, Manoa, HI 96822, USA. E-mail: noy@hawaii.edu. We thank Michael Hutchison, Hiro Ito, Nancy Marion, and Shang-Jin Wei for data, two anonymous referees, and the many useful comments we received from seminar participants at the Hebrew University, UCSC, UCLA, the University of Haifa, the University of Illinois (Urbana-Champaign), the University of Hawaii, Tel Aviv University, the University of Washington, and LACEA 2004. Any errors are ours. This paper summarizes the results in Aizenman and Noy (2004).
} 
In section 2 we outline a model in which financial openness is determined endogenously. The model integrates public finance and political-economy considerations, focusing on a developing country characterized by limited tax capacity and political instability. Fiscal outlays are financed by means of two taxes: a direct income tax and an implicit tax induced by capital controls. Both taxes are costly: the income tax is associated with deadweight losses due to the collection and enforcement costs. The tax capacity is impacted by the resources devoted to enforcement and administration. Similarly, enforcing capital controls entails costly policing to prevent illicit capital flight. There are two types of policymakers. The "responsible" one faces the canonic public finance problem: determining tax policies in order to maximize the representative consumer's welfare, subject to the need to fund a fiscal revenue stream. The second is of the extractive type, interested in obtaining resources for a narrow interest group.

In this set-up, financial openness is endogenously determined by the authority's choice of financial repression. This policy is tantamount to a tax on domestic saving, generating the incentive to engage in illicit capital flight in order to avoid the tax. Capital flight is intermediated via trade misinvoicing. ${ }^{1}$ Enforcing financial repression requires direct expenditure on monitoring and policing trade invoices, thereby greater trade openness increases enforcement costs. We show that financial repression characterizes countries that are below a certain threshold of fiscal efficiency-high enough cost of tax collection would induce the implementation of financial repression as a means of taxation. Countries typified by low trade openness and high saving are more likely to use financial repression. In these circumstances, higher tax collection costs, higher fiscal expenditure, and lower commercial openness would increase the "optimal" financial repression.

We also find that lower probability of staying in power reduces the optimal investment in tax capacity, and increases the likelihood that financial repression would be part of the menu of taxes. If the policymaker is maximizing the representative consumer's welfare, a higher probability of staying in power increases the investment in future tax capacity, reducing the optimal financial repression. If the policymaker is of the extractive type, reflecting the interests of narrow pressure groups, the tax would be set at the peak of the corresponding tax Laffer curve. The attitude of this policymaker towards capital controls is mixed-capital controls would be imposed on the representative consumer, while the fiscal surplus would be put in off-shore accounts, as insurance against losing power. In these circumstances, lower probability of staying in power increases capital flight and reduces financial repression.

We examine empirically some of the hypotheses suggested by our model. We estimate the level of de facto financial openness as a function of lagged trade openness and other variables. We find that de facto financial openness depends positively on lagged trade openness. These results suggest de facto sequencing, where greater de facto trade openness is associated with larger future de facto financial openness. The reverse association may also hold. Hence, we expect to find two-way positive linkages between financial and commercial openness and confirm these predictions empirically. We investigate the relative magnitudes of these directions of causality using the decomposition test developed in Geweke (1982). We find that almost all of the linear feedback between trade and financial openness can be accounted for by G-causality from financial openness to trade openness (53\%) and from trade to financial openness $(34 \%)$. The residual is due to simultaneous correlation between the two annual measures.

The evidence in the paper is in line with a recent contribution by Antràs and Caballero (2007). They introduce financial frictions to the $2 \times 2$ standard international trade model. Specifically, they assume that entrepreneurs in the relatively complex 
sector are endowed with essential skills, but due to informational frictions they can borrow only a fraction of their capital endowment. They find that trade and capital flows are complements, and that financially underdeveloped economies that liberalize trade may experience capital inflows. Our results are also consistent with the notion that a significant share of the volume of financial flows to and from developing countries is due to diversification of political risk, as in Dooley (1988). This interpretation may provide an additional rationale for our finding concerning the negative marginal association of democracy and financial openness. This finding also suggests that the "home bias" in the allocation of financial assets identified by the financial literature (in the OECD countries) may be less pronounced in developing countries because of political risk considerations.

\section{The Model}

This section extends Aizenman and Guidotti (1994), describing the links between trade and financial openness in a developing country characterized by limited tax capacity and political uncertainty. We consider a country where fiscal outlays are financed by a direct income tax and an implicit tax induced by capital controls. Both taxes are costly: the income tax is associated with deadweight losses due to collection and enforcement costs. The tax capacity is impacted by the resources devoted to enforcement and administration. Similarly, enforcing capital controls entails costly policing to prevent illicit capital flight. We assume a small, two goods, two-period economy. The consumer's utility is $V=u\left(X_{1}^{\alpha} Y_{1}^{\beta}\right)+u\left(X_{2}^{\alpha} Y_{2}^{\beta}\right) /(1+\rho), u^{\prime}>; u^{\prime \prime} \leq 0$; $\alpha+\beta=1$, where $X$ is the domestic good and $Y$ is the foreign, imported good. There are two types of policymakers. The "responsible" one, denoted by $w$, chooses public finance policies in order to maximize the representative consumer's welfare, subject to the need to fund the given fiscal revenue stream. The second type of policymaker, denoted by $n$, is of the extractive type, interested in obtaining resources for narrow interest groups. Consumers are endowed each period with $\bar{X}$ units of the domestic good. The authorities tax the income from the endowment $\bar{X}$ at a rate $t$. The consumer saves in period one $\bar{D}$, allocating it between domestic and foreign bonds, $D$ and $D^{*}$, respectively. The international real interest rate is $r^{*}$. The authorities impose capital control in the form of a tax on the foreign bond. Let $\phi$ denote the tax rate, implying that the domestic interest rate, $r$, is determined by $1+r=\left(1+r^{*}\right)(1-\phi)$. Consequently, the tax determines the premium between the foreign and domestic real interest $\phi=\left(r^{*}-r\right) /\left(1+r^{*}\right)$. The premium $\phi$ is also a measure of the intensity of financial controls. The existence of the premium implies that consumers would have the incentive to engage in illicit capital flight, in order to avoid the tax. This capital flight is intermediated via the trade account by trade misinvoicing, hence its potential magnitude would be determined by the volume of imports $\left(Y_{1}\right)$ and exports $\left(\bar{X}-X_{1}\right)$. Preventing illicit capital flows induced by a premium $\phi$ requires spending $\tau \bar{X}$ on enforcement. Assume that enforcement and the resultant premium are linked by the following reduced form: ${ }^{2} \phi=\phi\left[\tau \bar{X} / Y_{1}\right] ; \phi^{\prime}>0$; $\phi^{\prime \prime}<0$. This formulation assumes that larger trade openness requires an equiproportionate increase in enforcement in order to support the given premium. It also recognizes the diminishing marginal efficacy of enforcement. The tax on foreign bonds and the enforcement of financial repression implies that the consumer is indifferent to the domestic and the foreign bond. ${ }^{3}$

Enforcement of the income tax is associated with collection cost $\lambda_{i}(i=1,2)$ per one dollar of gross taxes applied for tax rates below $\bar{t}$, where $\bar{t}$ reflects the tax capacity. The net tax collected by a tax $t$ is $\left(1-\lambda_{i}\right) t_{i} \bar{X}$ for $t_{i}<\bar{t}_{i}$ and $\left(1-\lambda_{i}\right) \overline{t_{i}} \bar{X}$ for $t_{i} \geq \bar{t}_{i}$. The second 
period collection costs and tax capacity are determined by the first period investment rate in fiscal capabilities, denoted by $\psi$, where $\lambda_{2}=\lambda_{2}(\psi), \lambda^{\prime} \leq 0, \lambda^{\prime \prime} \geq 0 ; \bar{t}_{2}=\bar{t}_{2}(\psi) ; \bar{t}^{\prime} \geq 0$; $\bar{t}^{\prime \prime} \leq 0$. The net revenue from the income tax, plus the revenue from the domestic bond sold in period one, finances the fiscal expenditure on exogenous public spending $(G)$, plus the cost of the enforcement of capital controls and investment in fiscal capability $[(\tau+\psi) \bar{X}]$, plus the repayment of old debt. In these circumstances, financial repression imposes taxes on domestic savings at the premium rate, $\phi$. This tax has two components: first, it taxes foreign bonds, $D^{*}$, directly, at the premium rate; second, it reduces the cost of financing the domestic debt, $D$, at the premium rate. The sum of both implies that financial repression taxes domestic savings, $D^{*}+D$. Unlike the private sector, the effective real interest rate facing the fiscal authorities equals the foreign one. We consider two possible scenarios:

1. The first period policymaker is of type $w$, expecting to survive for the second period with probability $q$. Policy maker $w$ chooses the tax rates $t$, the enforcement $\tau$, and investment in tax capacity $\psi$ that would maximize the expected utility of the representative agent, subject to the fiscal and the private budget constraints, and the uncertainty regarding the future policymaker. With probability $1-q$, the second period policymaker would be of type $n$.

2. The first period policymaker is type $n$, reflecting the interests of a narrow pressure group. Policy maker $n$ chooses $\langle t, \tau, \psi\rangle$ that would maximize the expected utility of the narrow interest group, subject to the fiscal and the private budget constraints, and the uncertainty regarding the future policymaker. With probability $1-p$, the second period policymaker will be of type $w$.

The following results characterize the pattern of optimal taxes and the resulting financial repression [see Aizenman and Noy (2004) for the derivation]:

1. Financial repression is part of the optimal public finance of policymaker $w$ if $\lambda_{1} \bar{D} \phi^{\prime}(0)_{\mid \tau=0}>\beta$. Hence, regimes characterized by costly collection of taxes, low trade openness, and high saving are more likely to use financial repression. If $\lambda_{1} \bar{D} \phi^{\prime}(0)_{\mid \tau=0}>\beta$, the optimal financial repression increases with the collection costs associated with income taxes and drops with the economy's trade openness. This follows from the observation that greater trade openness increases the effective cost of enforcing financial repression, reducing thereby the usefulness of financial repression as an implicit tax.

2. Lower probability of staying in power (i.e. low $p$ and $q$ ) reduces the optimal investment in tax capacity, increases $\lambda$, and increases the likelihood that financial repression would be part of the menu of taxes. If the first period policymaker is of type $w$, a higher probability of staying in power for the second period would increase the first period investment in future tax capacity, reducing the optimal financial repression. If the first period policymaker is of type $n$, reflecting the interests of narrow pressure groups, the tax would be set at the peak of the corresponding tax Laffer curve, $t=\bar{t}$. The attitude of type $n$ policymaker towards capital controls is mixed-capital controls would be imposed on the representative consumer, while first period fiscal surplus would be put in off-shore accounts, as insurance against losing power. Lower probability of staying in power by the regime representing the narrow pressure group, $n$, increases capital flight and reduces financial repression. ${ }^{4}$

The model can be embodied in an overlapping generation structure, where the present investment in tax capabilities determines the collection cost and the tax capacity next period. We can also extend the model to allow concave collection costs. 
The probability of staying in power can be modeled in the context of a more elaborated economy. These extensions would not change the main results regarding the association between trade and financial openness.

Following the approach of Cukierman et al., (1992), one expects less polarized societies and better functioning democracies to be characterized by more efficient tax collection systems (hence by lower $\lambda$ ). Applying this conjecture, a more efficient tax system would be associated also with a lower tax rate, $t$, thereby reducing the attractiveness of capital flight. It can be verified that with low enough financial repression, the net effect of improving the tax system is to lower the incidence of capital flight, thereby reducing de facto financial integration. Of course, de facto financial openness is impacted by other considerations not addressed by the public finance model described above, such as differentials in discount rates and investment opportunities across countries, etc. One should view the above model as suggestive of possible links between macro- and political-economy factors and de facto openness, motivating the empirical research.

Our discussion so far has focused on the possibility that greater trade openness will lead to higher financial openness. It is reasonable to expect that the linkages between trade and financial openness operate in both directions, and that higher financial openness would lead to greater trade openness. ${ }^{5}$ A likely channel is vertical foreign direct investment (FDI). FDI allows multinationals to fragment production optimally, benefiting from the cost advantage associated with locating labor intensive production stages in labor abundant countries. A by-product of this fragmentation is the growth of two-way trade: higher imports of primary and intermediate products, followed by higher exports of the upgraded products.

The positive association between trade and financial openness may also be the outcome of political-economy factors. They propose an interest group theory of financial development whereby incumbents oppose financial development because it breeds competition. In these circumstances, the incumbents' opposition will be weaker when an economy allows both cross-border trade and capital flows. They predict that a country's domestic financial development should be positively correlated with trade openness, and they identify the time varying nature of this association. Another interesting approach linking trade and financial openness is Portes and Rey (2003), who show that international trade in both goods and assets are explained by similar gravity regressions.

We therefore expect to observe two-way linkages between trade and financial openness. In the next section, among other things, we will look at these causal links empirically. We first confirm the importance of lagged commercial openness in Granger-causing contemporaneous financial openness, after controlling for macro- and political-economy variables. Next, we show that lagged financial openness plays an important role in accounting for commercial openness. We close the empirical evaluation of this question by decomposing the relative quantitative importance of the two channels.

\section{The Empirical Model}

We measure de facto financial openness using the sum of total capital inflows and outflows (in absolute values) measured as a percent of gross domestic product. Capital flows are the sum of FDI, portfolio flows, and other investments. ${ }^{6}$ In terms of financial instability (measured as standard deviation), developing countries seem to experience much higher volatility relative to their degree of openness. This difference is most 
striking between developed countries and the East Asian emerging markets that appear to have similar levels of average openness but with much higher volatility. For our commercial openness index, we average the sum of exports and imports as a percentage of GDP over the previous 4 years $(t-1$ to $t-4)$. By averaging, we smooth out any fluctuations due to temporary changes in the terms of trade. Bivariate analysis clearly shows a partial correlation between the two annual measures of openness (stronger for the 1990s), but only a weak and unstable correlation between the gross and net financial flows.

As the previous theoretical discussion suggests, one of the determinants of de facto financial openness should be the legal impediments to financial flows. Accordingly, we include in our multivariate analysis two measures for restrictions on the capital account. The first, taken from Chinn and Ito (2006), is constructed using the data provided in the IMF's Annual Report on Exchange Arrangements and Exchange Restrictions. The second measure is constructed from Bekaert et al. (2005) by summing three binary indicators of the openness of equity markets.

For the political-economy determinants of financial openness, we concentrate our empirical investigation on three political-institutional measures: a democracy index, a measure of political competition, and a Herfindahl index for government fractionalization. Cukierman et al. (1992) argued that functioning democracies will tend to have more efficient tax collection systems. In our theoretical work, we concluded that the degree of tax collection costs will determine the degree of financial repression. To investigate this hypothesis we examine whether the capacity of the political system to prevent friction is a relevant measure. We expect less polarized societies and those in which conflicts are solved peacefully within the political system to have more efficient tax collection mechanisms in place. We employ a variable that measures the degree of democratic rule, and a variable that measures the degree of political competition within a polity. These indices are highly correlated even though they were constructed on different criteria and sources.

Another political-economy variable we use to examine the robustness of our results comes from a political dataset constructed at the World Bank (Keefer, 2002). Because we hypothesized that more polarized social and institutional arrangements will affect the efficiency of tax collections, we use an index that measures the fractionalization within government. Following the work of Wei (2000) and Dreher and Siemers (2003), we examine whether corruption matters for the degree of financial openness. To that end, we use a measure of corruption taken from the International Country Risk Guide. Besides democracy and competition variables, the other political variables do not seem significantly correlated. We also include a host of macroeconomic control variables. In all regressions we use the inflation rate, per capita gross domestic product, the government's budget surplus (as share of GDP), and a world interest rate. In order to examine whether the occurrence of financial crises matters, as they might systematically change the relationship between financial openness and our control variables, we include crises measures in several regressions. We attempted to include all 205 countries and territories for which data are available. Most of the data on financial flows are typically available only from the 1980s and only for a much smaller set of countries. Our dataset is therefore an annual panel of 83 countries for the years 1982-98.

We further investigate the robustness of our results by examining various subsamples. Notably, we hypothesize that results for OECD countries might be different from those for developing countries. We thus repeat our regressions for developed economies-which we define as those economies that were members of the OECD in 1990. We exclude island economies (as these are often used as off-shore banking 
centers and their level of de facto financial openness is often much higher). The Data Appendix in Aizenman and Noy (2004) provides a detailed summary of the variables, sources, and samples.

Based on our theoretical work, we estimate the statistical significance of various sources of financial repression by positing a linear structure for the determination of the level of financial openness whereby:

$$
F O_{i t}=\alpha+\beta_{1} X_{i t}+\beta_{2} \overline{C O}_{i t-1}+\beta_{3} P_{i t}+\varepsilon_{i t}, \text { with } \varepsilon_{i t}=\rho \varepsilon_{i t-1}+\mu_{i t} .
$$

The dependent variable $\left(F O_{i t}\right)$, financial openness for country $i$ at time $t$, is assumed to be dependent on an intercept (or, alternatively, separate country or regional intercepts), a vector $X_{i t}$ of macroeconomic control variables, an average of lagged commercial openness $\left(\overline{C O}_{i t-1}\right)$, a vector of political-institutional variables $\left(P_{i t}\right)$, and an error term. A Durbin-Watson statistic for all iterations of the model strongly indicates that the error terms are autocorrelated. The error term is thus assumed to have an AR(1) structure with $\mu$ iid. ${ }^{7}$ We estimate the model using the Prais-Winsten algorithm.

Table 1 includes results for our benchmark regressions. For the first stage regression, the $\mathrm{R}^{2}$ is between 0.20 and 0.67 depending on the exact specification and sample used. ${ }^{8}$ For the second stage, the model converges very quickly (within two iterations), and most of the coefficients for the benchmark control variables are robust to the inclusion

Table 1. Benchmark Model Results

\begin{tabular}{|c|c|c|c|c|c|c|}
\hline & (1) & (2) & (3) & (4) & (5) & (6) \\
\hline Per capita GDP & $\begin{array}{l}0.64 * * \\
(2.14)\end{array}$ & $\begin{array}{c}0.14 \\
(1.09)\end{array}$ & $\begin{array}{l}2.28 * * * \\
(4.09)\end{array}$ & $\begin{array}{l}2.14 * * * \\
(4.28)\end{array}$ & $\begin{array}{l}2.02 * * * \\
(3.67)\end{array}$ & $\begin{array}{l}1.41 * * * \\
(3.11)\end{array}$ \\
\hline $\begin{array}{r}\text { Budget surplus } \\
(\% \text { of GDP })\end{array}$ & $\begin{array}{l}-0.26^{*} \\
(-1.70)\end{array}$ & $\begin{array}{l}0.44 * * * \\
(4.60)\end{array}$ & $\begin{array}{l}-0.40 * * \\
(-2.07)\end{array}$ & $\begin{array}{l}-0.28^{*} \\
(-1.62)\end{array}$ & $\begin{array}{l}-0.42^{* *} \\
(-2.16)\end{array}$ & $\begin{array}{l}-0.26^{*} \\
(-1.81)\end{array}$ \\
\hline Inflation (CPI) & $\begin{array}{c}0.00 \\
(-0.16)\end{array}$ & $\begin{array}{l}-0.14 \\
(-1.46)\end{array}$ & $\begin{array}{c}0.00 \\
(-0.38)\end{array}$ & $\begin{array}{c}0.00 \\
(-0.27)\end{array}$ & $\begin{array}{c}0.00 \\
(-0.47)\end{array}$ & $\begin{array}{c}0.00 \\
(-0.28)\end{array}$ \\
\hline US Treasury bill rate & $\begin{array}{l}-0.32 \\
(-0.88)\end{array}$ & $\begin{array}{l}-0.03 \\
(-0.14)\end{array}$ & $\begin{array}{l}-0.26 \\
(-0.53)\end{array}$ & $\begin{array}{l}-0.31 \\
(-0.70)\end{array}$ & $\begin{array}{l}-0.19 \\
(-0.38)\end{array}$ & $\begin{array}{l}-0.13 \\
(-0.32)\end{array}$ \\
\hline $\begin{array}{l}\text { Trade openness } \\
\text { (average for } \\
\mathrm{t}-1, \ldots, \mathrm{t}-4 \text { ) }\end{array}$ & $\begin{array}{l}0.11^{* * * *} \\
(9.08)\end{array}$ & $\begin{array}{l}0.09 * * * \\
(7.99)\end{array}$ & $\begin{array}{l}0.07 * * * \\
(4.52)\end{array}$ & $\begin{array}{l}0.08^{* * * *} \\
(5.51)\end{array}$ & $\begin{array}{l}0.08 * * * \\
(5.15)\end{array}$ & $\begin{array}{l}0.09 * * * \\
(7.19)\end{array}$ \\
\hline Democracy/autocracy & $\begin{array}{l}-0.44 * * * \\
(-2.71)\end{array}$ & $\begin{array}{l}-0.40 \\
(-0.37)\end{array}$ & $\begin{array}{l}-0.51 * * \\
(-2.48)\end{array}$ & $\begin{array}{c}-0.26^{*} \\
(-1.60)\end{array}$ & & \\
\hline Corruption & $\begin{array}{l}-2.01 * * \\
(-2.23)\end{array}$ & $\begin{array}{l}-0.12 \\
(-0.25)\end{array}$ & $\begin{array}{l}-2.74 * * \\
(-2.24)\end{array}$ & & $\begin{array}{l}-1.86^{*} \\
(-1.59)\end{array}$ & \\
\hline The 1990s & $\begin{array}{l}4.89 * * * \\
(2.99)\end{array}$ & $\begin{array}{l}3.04 * * * \\
(3.71)\end{array}$ & $\begin{array}{l}4.65^{* *} \\
(2.10)\end{array}$ & $\begin{array}{l}4.04 * * \\
(2.08)\end{array}$ & $\begin{array}{r}3.52 * \\
(1.62)\end{array}$ & $\begin{array}{l}3.83^{* *} \\
(2.17)\end{array}$ \\
\hline$\rho$ & $0.88 * * *$ & $0.86^{* * *}$ & $0.88 * * *$ & $0.88 * * *$ & $0.88 * * *$ & $0.88 * * *$ \\
\hline Observations & 829 & 222 & 607 & 694 & 607 & 768 \\
\hline Sample & ALL & OECD & DEV & DEV & DEV & DEV \\
\hline
\end{tabular}

Notes: $\mathrm{t}$-statistics for all variables are given in parentheses. The left-hand side variable is the sum of financial inflows and outflows (as \% of GDP). Estimation using the Prais-Winsten algorithm assuming an AR(1) process for the error terms. $\rho$ is the correlation coefficient for the $\operatorname{AR}(1)$ process: $\varepsilon_{i t}=\rho \varepsilon_{i t-1}+\mu_{i t}$. ALL denotes the whole sample; OECD includes only OECD countries; DEV denotes the developing countries sample. * Significant at $10 \%$; ** significant at $5 \%$; *** significant at $1 \%$. 
and exclusion of other variables. In column (1) of Table 1, which includes the full sample, we already observe many of the results that remain throughout. The coefficient for per capita GDP is always significantly positive-i.e. an increase in GDP per capita increases financial openness (except for a regression containing only OECD countries in which the coefficient is insignificant). We find that an increase in per capita GDP of PPP $\$ 1000$ will facilitate a 0.14 to 2.28 percentage points increase in the volume of capital flows (as percent of GDP). The ratio of budget surplus to GDP is typically significant and always negative for developing countries. A bigger budget deficit will increase de facto financial openness. Again, this result does not hold for our OECD subsample; for this case, reported in Table 1 column (2), the budget surplus coefficient is positive and significant. ${ }^{9}$ The inflation rate and the world interest rate are always insignificantly different from zero. But, as with the previous results, the coefficients for inflation and the world interest rate seem to be different for the OECD subsample; although these are still insignificant for standard significance levels, the effect of inflation on financial openness is larger (and negative) for the OECD countries and the effect of the US T-Bill rate is smaller. Both these results correspond with our intuition. We also include a binary variable for the 1990s and, as expected, the coefficient for this variable is always positive and significant. This increase in capital flows is found to be between 1.3 and 4.9 percent of GDP.

Additionally, we find that the trade openness coefficient is always positive and highly significant. As this variable describes the average openness over the previous four years, we find that a history of more commercial openness will increase financial openness significantly. This result is robust to all the iterations we present in Tables 1 and 2. Before discussing our empirical analysis of the political-economy determinants of international financial flows, we note that including the corruption variable in our regressions also yields negative and significant coefficients in almost all the iterations of the model. Similar results from different data are analyzed in detail in Wei (2000) and Dreher and Siemers (2003).

We examine the effect of the nature of the political regime on financial openness (this index is between 10 (full democracy) and-10 (full autocracy)). For the full sample (Table 1 column 1) and the developing countries subsamples (Table 1 column 3 ), the coefficient for this variable is negative, significant, and apparently large. Any one-point increase in this index (out of the 20 points difference between full autocracy and democracy) reduces financial openness (international financial flows) by almost onehalf of a percentage point of GDP.

Because the results for the OECD subsample are consistently different, and our theoretical modeling is focused on developing countries, we give most attention to the developing countries subsample (these include all non-OECD countries that are not islands/financial centers). Columns 5 and 6 in Table 1 repeat our specification for the developing countries sample but exclude the regime variable in column 5 and both the regime and corruption measures in column 6 . In both cases, we find that all the other results reported above remain robust to these omissions.

We calculate the quantitative significance of our findings for the benchmark model. For the sample of developing countries, we find that a one standard deviation increase in the commercial openness is associated with a 9.5 percentage points increase in $d e$ facto financial openness ( $\%$ of GDP), a one standard deviation increase in the democratization index reduces financial openness by 3.5 percentage points, and a one standard deviation increase in corruption is associated with a reduction of financial openness by 3.1 percentage points. Similarly, the corresponding associations for the whole sample are 12.3,3.1, and 2.9. Furthermore, a developing country will have: higher 
financial openness (measured as 3 additional percentage points of GDP) were it to have the median level of trade openness of an OECD country; would be $2.2 \%$ less open were it as democratic as the typical OECD country; and $4 \%$ more open to financial flows were it less corrupt, as the typical developed country is.

In Table 2 columns (1)-(4) we further investigate the political-economy nature of financial openness by replacing the democracy/autocracy (regime) variable with two others: a measure of political competition, and an index of government fractionalization. For the political competition variable, we find that increased institutionalized competition within the polity decreases financial openness. Thus, a more openly competitive, free, and inclusive political system will lead to lower levels of financial openness, after controlling for incomes, macroeconomic policy (inflation and budget surpluses), interest rates, and commercial openness. For the government fractionalization index (reported in Table 2 columns 3 and 4), we find that the more a government is fractionalized (the ruling coalition includes more political parties), the higher is the financial openness. Quantitatively, the estimated coefficient of 1.4-1.9 does not seem to suggest a very large effect on the level of international financial flows.

In columns (5)-(6) of table 2 we re-estimate our benchmark specification (Table 1 column 3) but also include the de jure measures of financial openness (openness of the capital account). We use two measures. The first, taken from Chinn and Ito (2006), is constructed using the IMF data provided in its Annual Report on Exchange Arrangements and Exchange Restrictions (column 5). The second measure is constructed by adding the three binary indicators of equity markets openness available in Bekaert et al. (2005). Interestingly, the coefficient for the Chinn-Ito measure of restrictions is not significant in this specification, nor in the other specifications we ran. The Bekaert et al. (2005) index is positive and significant at the $10 \%$ level. These results merit further inquiry because of the questions they pose; and the importance of the de jure environment on the de facto amount of capital flows has not been examined thoroughly in the literature. Nevertheless, our main results with respect to commercial openness and the political regime remain significant also when the de jure measures are included; though the corruption coefficient is no longer always significant, possibly reflecting a correlation between corruption and the decision by the authorities to use financial repression. In column 7 of Table 2, we utilize a different measure of trade openness. The traditional measure of the sum of exports and imports (\% of GDP) does not capture accurately trade openness in countries that promote exports but discourage imports. Thus, we compute an alternative index of openness based only on imports. Results remain very similar for all variables, both statistically and in magnitude, but for a larger coefficient for the trade openness measure. ${ }^{10}$

In addition to the specifications discussed above, we tested a number of alternative specifications of our empirical model in order to verify the robustness of our results. Because of space considerations we do not include the full specifications in our tables, but all these results are available upon request. First, we hypothesized that financial crises (either banking or currency crises) might significantly affect the level of financial openness in general and more specifically the use of financial repression. Interestingly, in all iterations of the model we attempted, none of the crises coefficients comes out significant. ${ }^{11}$ Second, besides including the average of past commercial openness, we also included in our specification the contemporaneous TRADE/ GDP variable and obtained the following. In all cases, the lagged commercial openness variable remains positive and highly significant. For the developing countries sample, as well as the whole sample, the lagged average is positive and highly significant with a now larger coefficient ( 0.20 and 0.21 , respectively), while the contemporaneous variable is 


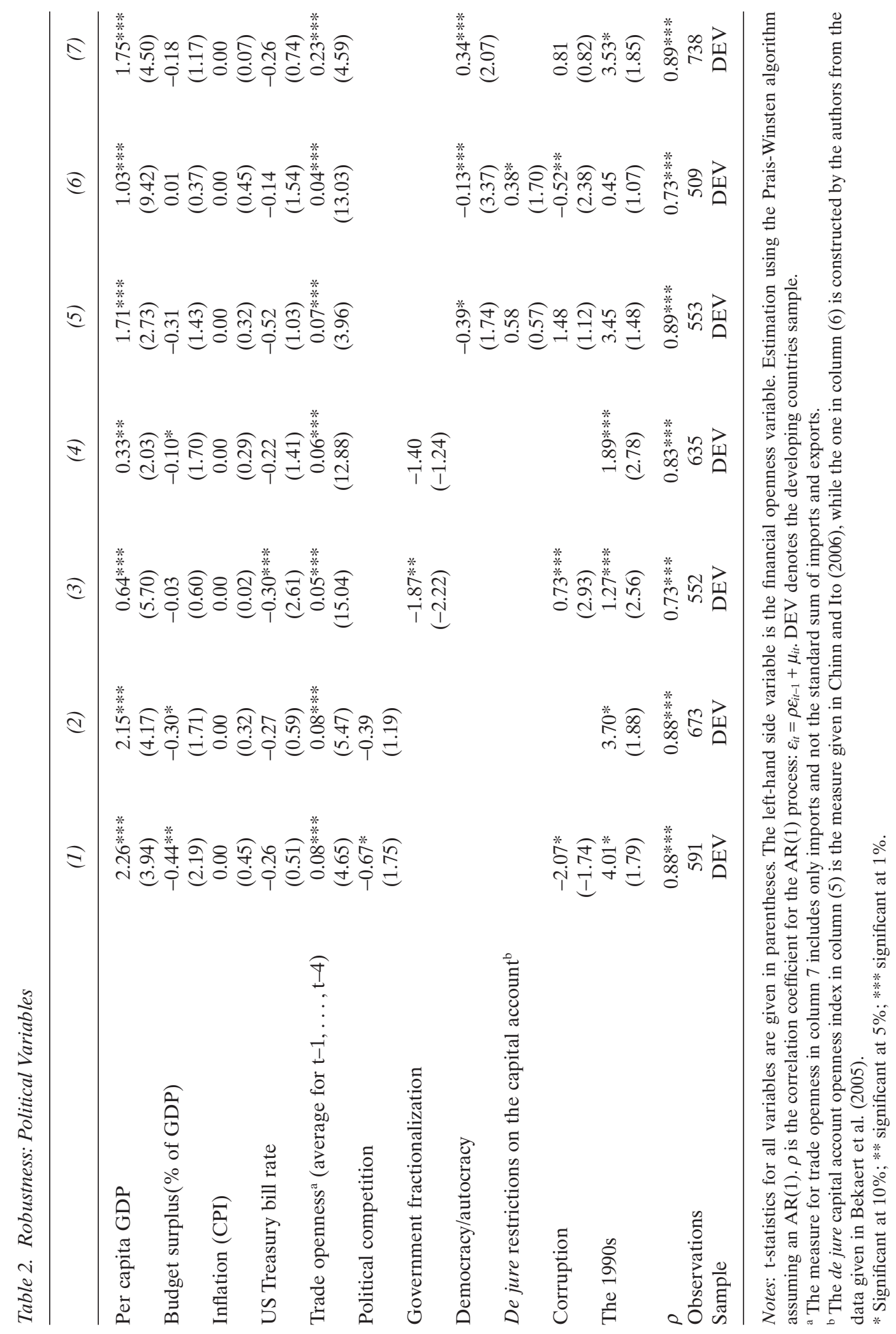




\begin{tabular}{lcc}
\hline & $\begin{array}{c}\text { Pecomposition } \\
\text { of feedback }\end{array}$ & $\begin{array}{c}\text { Percent of } \\
\text { overall linear } \\
\text { feedback }\end{array}$ \\
\hline From financial openness to commercial openness $\left(F_{F O \rightarrow C O}\right)$ & $0.27^{* * *}$ & 53 \\
$\begin{array}{l}\text { From commercial openness to financial openness }\left(F_{C O \rightarrow F O}\right) \\
\text { Simultaneous causality between financial and commercial } \\
\text { openness }\left(F_{F O} \cdot C O\right)\end{array}$ & $0.17^{* * *}$ & 34 \\
\hline
\end{tabular}

Notes: *** represents rejection of $\mathrm{H}_{0}$ : no causality at the $1 \%$ significance level based on a $\chi^{2}$ test as in Geweke (1982). The feedback is defined in equations (2)-(4). The percent of the total linear feedback between the two time series is defined in equation (3).

negative and significant. For the OECD sample, the lagged average is still positive and highly significant, while the contemporaneous variable is now positive but insignificant. The sum of the two coefficients is always positive and highly significant for the three different samples. ${ }^{12}$

As the political and institutional variables we use do not vary sufficiently over time we do not present results for the model estimated with country effects. Typically, the goodness of fit is higher but the independent political-institutional variables lose most of their statistical significance (as would be expected). We include regional effects (binary variables for Latin America and East Asia) in our large and developing countries samples. Time effects do not provide any additional explanatory power besides a significant finding for the 1990s (reported above).

\section{Causality}

In the previous section we have established that past trade openness Granger-causes financial openness (see Granger, 1969). ${ }^{13}$ The Granger framework assumes no instantaneous feedback between the two series and is oriented to inspect for uni-directional causality (Geweke, 1982). Yet, because causality may also run from past financial openness to present trade openness we also estimate the opposite specification: $C O_{i t}=\gamma+\delta_{1} X_{i t}+\delta_{2} \overline{F O}_{i t-1}+\delta_{3} F O_{i t-1}+\delta_{4} P_{i t}+\eta_{i t}$.

We use the same assumptions, methodology, definition of variables, and samples as before. Results for several specifications are reported in the working paper. Our focus is the determination of financial openness and we therefore concentrate our attention on the financial openness index. In all the specifications reported in Table 6 of Aizenman and Noy (2004) it is apparent that financial openness also Granger-causes trade openness. These results hold whether we examine a one-year lag of the financial openness measure, or a four-year average of past financial openness for the various subsamples previously described. We also implement a different causality test that is more robust to alternative assumptions about the error terms that are more likely to hold for time series - the test is described in Holmes and Hutton (1992). Results indicate a more robust evidence of prima facie causality from finance to trade than from trade to finance.

We also find an asymmetric effect of de jure restrictions on de facto openness: while there is only weak evidence that de jure restrictions on capital mobility impact de facto financial openness, de jure restrictions on the current account have large adverse effects on commercial openness. These findings suggest that it's much easier to evade restrictions on capital account convertibility than restrictions on commercial trade. 
In Granger (1969), the possibility of simultaneous causality between the two time series is ignored. In principle, dividing the time series into shorter periods should enable us to identify accurately the exact chronology of effects-this is often impossible in practice. As we employ annual data, and because financial flows respond quickly to exogenous shocks, it is reasonable to expect that our data will also contain what appears to be instantaneous causality between trade and financial openness. Geweke (1982) suggests a methodology to distinguish between (temporal) causality (from $x$ to $y$ and from $y$ to $x$ ) and simultaneous causality (between the two). We briefly describe the methodology and provide results. ${ }^{14}$

First we estimate the following five equations using a panel fixed-effects leastsquares estimation for our developing countries sample.

$$
\left\{\begin{array}{l}
F O_{i t}=\alpha_{i}^{1}+\sum_{s=1}^{p} \beta_{1 s}^{1} F O_{i t-s}+\sum_{s=0}^{p} \beta_{2 s}^{1} C O_{i t-s}+\varepsilon_{i t}^{1} \\
F O_{i t}=\alpha_{i}^{2}+\sum_{s=1}^{p} \beta_{1 s}^{2} F O_{i t-s}+\sum_{s=1}^{p} \beta_{2 s}^{2} C O_{i t-s}+\varepsilon_{i t}^{2} \\
F O_{i t}=\alpha_{i}^{3}+\sum_{s=1}^{p} \beta_{1 s}^{3} F O_{i t-s}+\varepsilon_{i t}^{3} \\
C O_{i t}=\alpha_{i}^{4}+\sum_{s=1}^{p} \beta_{1 s}^{4} C O_{i t-s}+\sum_{s=1}^{p} \beta_{2 s}^{4} F O_{i t-s}+\varepsilon_{i t}^{4} \\
C O_{i t}=\alpha_{i}^{5}+\sum_{s=1}^{p} \beta_{1 s}^{5} C O_{i t-s}+\varepsilon_{i t}^{5}
\end{array} .\right.
$$

Next, following Geweke's (1982) notation, we define $F_{C O \rightarrow F O}$ as the linear feedback (i.e. G-causality) from trade openness to financial openness, $F_{F O \rightarrow C O}$ as the G-causality from financial openness to trade openness, and $F_{F O} \cdot C O$ as the instantaneous linear feedback between the two series. ${ }^{15} F_{F O, C O}$, defined as the total measure of linear dependence between the two series, is therefore given by:

$$
F_{F O, C O}=F_{F O \rightarrow C O}+F_{C O \rightarrow F O}+F_{F O \cdot C O} .
$$

Given these definitions, Geweke (1982) concluded the following:

$$
\left\{\begin{array}{l}
F_{F O \rightarrow C O}=\log \left[\operatorname{var}\left(\varepsilon_{i t}^{5}\right) / \operatorname{var}\left(\varepsilon_{i t}^{4}\right)\right] \\
F_{C O \rightarrow F O}=\log \left[\operatorname{var}\left(\varepsilon_{i t}^{3}\right) / \operatorname{var}\left(\varepsilon_{i t}^{2}\right)\right] . \\
F_{F O \bullet C O}=\log \left[\operatorname{var}\left(\varepsilon_{i t}^{2}\right) / \operatorname{var}\left(\varepsilon_{i t}^{1}\right)\right]
\end{array}\right.
$$

Geweke (1982) showed that the null hypothesis $\left(\mathrm{H}_{0}: F=0\right)$ can be statistically examined using the $\chi^{2}$ distribution. In estimating (3), we started with three lags $(p=3)$ and reduced step-wise the number of lags using the Akaike Information criterion. In all cases, it turned out that a single lag contained all the information required to estimate the model; we set $p=1$ throughout. Table 3 provides our results. Most of the linear feedback between trade and financial openness $(87 \%)$ can be accounted for by Granger-causality from financial openness to trade openness (53\%) and from trade to financial openness (34\%). Simultaneous correlation between the two only accounts for $13 \%$ of the total linear feedback between the two series.

When we repeated this algorithm using the same methodology but including in the regressions the control variables previously described we obtained qualitatively and quantitatively very similar results for the feedback measures. We also examined the 
robustness using a theoretically equivalent but slightly different set of equations. We replaced the first equation in system (2) with

$$
\begin{aligned}
& C O_{i t}=\alpha_{i}^{1}+\sum_{s=0}^{p} \beta_{1 s}^{1} F O_{i t-s}+\sum_{s=1}^{p} \beta_{2 s}^{1} C O_{i t-s}+\varepsilon_{i t}^{1} \text { and } \\
& F_{F O \cdot C O}=\log \left[\operatorname{var}\left(\varepsilon_{i t}^{4}\right) / \operatorname{var}\left(\varepsilon_{i t}^{1}\right)\right] .
\end{aligned}
$$

The results we obtained were very similar. Similar results are also obtained when, following Johnson and Soenen (2004), we estimate the equations using seemingly unrelated regressions methodology. Because we reported evidence of more financial and trade openness in the 1990s, we examined the difference in the measured feedback effects between the two subsamples. While the measured magnitude of the feedback effects is significantly smaller, we found no evidence that the relative importance of the two feedback channels (from trade to finance and from finance to trade) has changed. We applied similar analysis to investigate the intertemporal linkages between disaggregated measures of trade and FDI. We found that the strongest feedback between the trade subaccounts is between FDI and manufacturing trade—see Aizenman and Noy (2006).

\section{Concluding Remarks}

Our analysis indicates that the de facto financial openness of developing countries is a complex endogenous variable, systematically impacted by economic and politicaleconomy factors. For a sample of developing countries, we find that a one standard deviation increase in the commercial openness index is associated with a $9.5 \%$ increase in de facto financial openness (international financial flows as percent of GDP).

One should be careful in attaching normative implications to these findings. Yet, the results reported in this paper may provide some guidelines to policymakers. For example, in an era of rapidly growing trade integration, countries cannot choose financial openness independently of their degree of openness to trade. A country that undergoes rapid commercial integration will find it impractical or even impossible to enforce rigid de facto financial repression. Hence, the question for China is not if, but rather when and how, to implement de jure financial integration. A remaining empirical challenge is to disaggregate de facto financial openness into its various components. Because each type of flow can be taxed differently with varying degrees of efficiency in tax collection, and faces different degrees of expropriation risk, one can expect the determinants of openness for each type of flow to be quite different.

\section{References}

Aizenman, J. and P. Guidotti, "Capital Controls, Collection Costs, and Domestic Public Debt," Journal of International Money and Finance (1994):41-54.

Aizenman, J. and I. Noy, "Endogenous Financial and Trade Openness," NBER Working Paper 10496 (2004).

_ , "FDI and Trade_-Two Way Linkages?" Quarterly Review of Economics and Finance 46 (2006):317-37.

Alesina, A. and G. Tabellini, "External Debt, Capital Flight, and Political Risk," Journal of International Economics 27 (1989):199-220.

Antràs, P. and R.J. Caballero, "Trade and Capital Flows: A Financial Frictions Perspective," mimeo, MIT (2007).

Bekaert, G., C.R. Harvey and C. Lundblad, "Does Financial Liberalization Spur Growth?" Journal of Financial Economics 77 (2005):3-55. 
Boyce, L. and J.K. Ndikumana, "Public Debts and Private Assets: Explaining Capital Flight from Sub-Saharan African Countries," World Development (2003):107-30.

Calderón, C. and L. Liu, "The Direction of Causality between Financial Development and Economic Growth," Journal of Development Economics 72 (2003):321-34.

Chinn, M. and H. Ito, "What Matters for Financial Development? Capital Controls, Institutions, and Interactions," Journal of Development Economics 81 (2006):163-92.

Chong, A. and C. Calderón, "Causality and Feedback Between Institutional Measures and Economic Growth," Economics and Politics 12 (2000):69-81.

Claessens, S. and D. Naudé, "Recent Estimates of Capital Flight," World Bank Policy Research Working Paper 1186 (1993).

Cukierman, A., S. Edwards, and G. Tabellini, "Seigniorage and Political Instability," American Economic Review 82 (1992):537-55.

Dooley, M., "Capital Flight: A Response to Differences in Financial Risks," IMF Staff Papers 35(3) (1988).

Dooley, M. and K. Kletzer, "Capital Flight, External Debt and Domestic Policies," Federal Reserve Bank of San Francisco Review 3 (1994):24-38.

Dreher, A. and L. Siemers, "The Intriguing Nexus Between Corruption and Capital Account Restrictions," mimeo, University of Goettingen (2003).

Geweke, J., "Measurement of Linear Dependence and Feedback Between Multiple Time Series," Journal of the American Statistical Association 77 (1982):304-13.

—_, "Measures of Conditional Linear Dependence and Feedback Between Time Series," Journal of the American Statistical Association 79 (1984):907-15.

Giovannini, A. and M. de Melo, "Government Revenue from Financial Repression," American Economic Review 83 (1993):953-63.

Granger, C., "Investigating Causal Relations by Econometric Models and Cross-spectral methods," Econometrica 37 (1969):424-38.

- "Some Recent Developments in a Concept of Causality," Journal of Econometrics 39 (1988):199-212.

Helpman, E. and A. Razin, A Theory of International Trade Under Uncertainty, New York: Academic Press (1978).

Henry, P.B., "Capital Account Liberalization, the Cost of Capital, and Economic Growth," American Economic Review 93 (2003):91-6.

Holmes, J. and P. Hutton, “A New Test of Money-Income Causality," Journal of Money, Credit and Banking 24 (1992):338-55.

Hutchison, M. and I. Noy, "How Bad Are Twins? Output Costs of Currency and Banking Crises," Journal of Money, Credit and Banking 37 (2005):725-52.

International Monetary Fund, Annual Report on Exchange Arrangements and Exchange Restrictions, Washington, DC (various years).

Johnson, B. and L. Soenen, "The US Stock Market and the International Value of the US Dollar," Journal of Economics and Business 56 (2004):469-81.

Keefer, P., "DPI2000: Database of Political Institutions: Changes and Variable Definitions," mimeo, World Bank (2002).

Pierce, D., "Comment: Measurement of Linear Dependence and Feedback Between Multiple Time Series," Journal of the American Statistical Association 77 (1982):315-16.

Political Risk Services, International Country Risk Guide, Syracuse, NY (various years).

Portes, R. and H. Rey, "The Determinants of Cross Border Equity Flows," MS, Princeton University (2003).

Prasad, E., K. Rogoff, S.-J. Wei, and A. Kose, "Effects of Financial Globalization on Developing Countries: Some Empirical Evidence," mimeo, IMF (2003).

Rodrik, D., "Who Needs Capital-Account Convertibility?" in P. Kenen (ed.), Should the IMF Pursue Capital Account Convertibility?, Essays in International Finance 207, Princeton: Princeton University Press ((1999).

Talvi, E. and C. Végh, "Tax Base Variability and Procyclical Fiscal Policy,” NBER working paper 7499 (2000). 
Tornell, A. and A. Velasco, "Tragedy of the Commons and Economic Growth: Why Does Capital Flow from Poor to Rich Countries?" Journal of Political Economy 100 (1992):1208-31.

Wei, S.-J., "How Taxing is Corruption on International Investors?" The Review of Economics and Statistics 82 (2000):1-11.

Wei, S.-J. and Y. Wu, "The Life-And-Death Implications of Globalization," mimeo, IMF (2002). Zellner, Arnold, "Comment: Measurement of Linear Dependence and Feedback Between Multiple Time Series," Journal of the American Statistical Association 77 (1982):313-314.

\section{Notes}

1. See Giovannini and de Melo (1993) for documenting and measuring financial repression as an implicit tax on savings. See Dooley (1988), Tornell and Velasco (1992), and Dooley and Kletzer (1994) on capital flight as a means of risk diversification. See Claessens and Naudé (1993) and Boyce and Ndikumana (2003) for discussions on trade mis-invoicing and capital flight.

2. The potential capital flight is assumed to be proportional to imports. Similar results would hold if one assumed that potential capital flight be proportional to (imports + exports).

3. To simplify notation, we assume that the enforcement prevents all tax evasion. The analysis can be extended to account for random interception of capital flight, where a higher $\tau$ increases the probability of interception (see an earlier version of our paper, Aizenman and Noy (2004)).

4. Russia in the early 1990s may provide a good case study. Alesina and Tabellini (1989) discuss a model where political instability and polarization determine the incidence of capital flight.

5. See Helpman and Razin (1978) for an integrated theory of trade in goods and securities.

6. Wei and $\mathrm{Wu}$ (2002) previously used this financial openness variable and made it available to us. See [Aizenman and Noy (2004)] for a detailed description of our data for financial openness. 7. $E\left(\mu_{t}\right)=0 ; E\left(\mu_{t}^{2}\right)=\sigma_{u}^{2}$; and $\operatorname{Cov}\left(\mu_{t}, \mu_{s}\right)=0$ for $t \neq s$.

8. The higher $\mathrm{R}^{2}$ values are generally for the models that include more political-institutional variables and for the developing and OECD subsamples.

9. The disparity between the impacts of budget surplus in developing and OECD countries may be explained by the differential cyclical patterns of fiscal policy. In contrast to the OECD countries, fiscal policy tends to be procyclical in developing countries. Financial crises tend to lead to recessions in developing countries, inducing abrupt fiscal adjustment and reducing fiscal deficits. These observations may lead to the positive association between smaller budget deficits and lower de facto financial openness, as in Talvi and Végh (2000).

10. The increase in the magnitude of the coefficient is either because the feedback effects between import flows and financial flows are stronger, or because there is a high correlation between exports and imports. Our new measure is therefore much smaller.

11. We utilized a number of variants of these binary crisis indicators (currency crisis and banking crisis) but never rejected the null (no effect). The crisis measures are described in Hutchison and Noy (2005).

12. One possible interpretation is that major recessions in developing countries (potentially triggered by capital flight) are associated with a drop in commercial openness, as would be the case if the drop in imports dominated any increase in exports. Likewise, capital flight may increase financial openness. It is difficult to provide a better rationale without desegregating financial openness into its subaccounts.

13. Holmes and Hutton (1992) use the term "prima-facie causality." They distinguish between this and "true causality" which is impossible to infer without strong structural assumptions.

14. Readers may also consult Geweke (1984) and Granger (1988). The only applications we are aware of which apply this methodology to macroeconomic data series are Chong and Calderón (2000) and Calderón and Liu (2003). Several papers in finance have employed the same methodology.

15. Geweke (1982) preferred the term "linear feedback". Pierce (1982), in a comment on Geweke's work, argued that a more appropriate term to describe the measures defined in our equations (9)-(10) in Aizenman and Noy (2004) would be "G-causality." Zellner (1982), in another comment, argues that the word "causality" should not be used if it is only based on statistical observed relationships rather than together with economic theory. 